\title{
SOURCES AND CREDITS
}

"The Bible As a Source for Philosophical Reflection" was originally published in The Routledge History of Jewish Philosophy, ed. Daniel Frank and Oliver Leaman (New York and London: Routledge, 1997).

"Maimonides' Moral Theory" was originally published in The Cambridge Companion to Maimonides, ed. Kenneth Seeskin (New York: Cambridge University Press, 2005).

"Worship, Corporeality and Human Perfection," was originally published in The Thought of Moses Maimonides, ed. Ira Robinson et. al (Lewiston/Queenston/ Lampeter: Edwin Mellen Press, 1990). Reprinted by permission of the publisher.

"The Integration of Torah and Culture: Its Scope and Limits in The Thought of Rav Kook," originally appeared in Hazon Nahum: Studies in Jewish Law, Thought and History Presented to Dr. Norman Lamm on the Occasion of his Seventieth Birthday, ed. Yaakov Elman and Jeffrey Gurock (New York: The Michael Scharf Publication Trust of the Yeshiva University Press, 1997). Reprinted by permission of the publisher.

"Is Rav Kook A Model of 'Openness'?" was originally published under a different title in Engaging Modernity, ed. Moshe Sokol (Lanham, MD: Jason Aronson, an imprint of Rowman \& Littlefield, 1997). Reprinted by permission of Rowman \& Littlefield.

"Science and Religious Consciousness in the Thought of Rabbi Joseph B. Soloveitchik" was originally published in Hebrew in Emunah bi-Zemannim Nishtannim, ed. Avi Sagi (Jerusalem: World Zionist Organization, Department for Torah Education and Culture, 1996). The final section is an abridged version of "The Rav and Torah u-Madda," in Mentor of Generations: Reflections on Rabbi Joseph B. Soloveitchik, ed. Zev Eleff (Jersey City, NJ: Ktav Publishing, 2008). 
"Divine Intervention and Religious Sensibilities" was originally published in Divine Intervention and Miracles in Jewish Theology, ed. Dan Cohn-Sherbok (Lewiston/Queenston/Lampeter: Edwin Mellen Press, 1990). Reprinted by permission of the publisher.

"From Anthropology to Metaphysics" was originally published in Judaism and Modernity: The Religious Philosophy of David Hartman, ed. Jonathan W. Malino (Burlington, VT and Hampshire, England: Ashgate, 2004). Reprinted by permission of Jonathan W. Malino.

"Is Matter All That Matters? Judaism, Free Will, and the Genetic and Neuroscientific Revolutions" was originally published in Judaism, Science and Moral Responsibility, ed. Yitzhak Berger and David Shatz (Rowman \& Littlefield, 2006). Reprinted by permission of the publisher.

“'From the Depths I Have Called to You': Jewish Reflections on September $11^{\text {th }}$ and Contemporary Terrorism" was originally published as a monograph by Yeshiva University in 2002.

"Does Jewish Law Express Jewish Theology?: The Curious Case of Theodicies" is published here for the first time. It is an abridged version of a paper to be published in a forthcoming Festschrift for Saul Berman, Misphetei Shalom, ed. Yamin Levy (Ktav Publishing Co.)

"Beyond Obedience: The Ethical Theory of Rabbi Walter Wurzburger," was originally published in Tradition (1996). Reprinted by permission of The Rabbinical Council of America.

"As Thyself": The Limits of Altruism in Jewish Ethics" was originally published in Reverence, Righteousness and Rahamanut: Essays in Memory of Rabbi Dr. Leo Jung, ed. Jacob J. Schacter (Jason Aronson, an imprint of Rowman \& Littlefield), 1992. Reprinted by permission of the publisher.

"Concepts of Autonomy in Jewish Medical Ethics" was originally published in Jewish Law Annual 12 (1997). Reprinted by permission of The Institute for Jewish Law at Boston University School of Law.

"The Overexamined Life is Not Worth Living" appeared in God and the Philosophers: The Reconciliation of Faith and Reason, ed. Thomas V. Morris (New York: Oxford University Press, 1994). Reprinted by permission of the publisher. 